\title{
Author Correction: Hypervirulent Listeria monocytogenes clones' adaptation to mammalian gut accounts for their association with dairy products
}

Mylène M. Maury 1,2,3, Hélène Bracq-Dieye ${ }^{1,2}$, Lei Huang ${ }^{1,4}$, Guillaume Vales ${ }^{1,2}$, Morgane Lavina1, Pierre Thouvenot ${ }^{1,2}$, Olivier Disson ${ }^{1}$, Alexandre Leclercq (1D 1,2, Sylvain Brisse ${ }^{3,6}$ \& Marc Lecuit (D) 1,2,5

Correction to: Nature Communications https://doi.org/10.1038/s41467-019-10380-0, published online 06 June 2019

The original version of this Article contained an error in the spelling of the word "adaptation" both in the Title and Abstract, which was incorrectly written as "adaption". This has been corrected in both the PDF and HTML versions of the Article.

Published online: 06 August 2019

\begin{abstract}
(c) Open Access This article is licensed under a Creative Commons Attribution 4.0 International License, which permits use, sharing, adaptation, distribution and reproduction in any medium or format, as long as you give appropriate credit to the original author(s) and the source, provide a link to the Creative Commons license, and indicate if changes were made. The images or other third party material in this article are included in the article's Creative Commons license, unless indicated otherwise in a credit line to the material. If material is not included in the article's Creative Commons license and your intended use is not permitted by statutory regulation or exceeds the permitted use, you will need to obtain permission directly from the copyright holder. To view a copy of this license, visit http://creativecommons.org/licenses/by/4.0/.
\end{abstract}

(C) The Author(s) 2019

\footnotetext{
${ }^{1}$ Biology of Infection Unit, Inserm U1117, Institut Pasteur, 75015 Paris, France. ${ }^{2}$ National Reference Centre and WHO Collaborating Centre for Listeria, Institut Pasteur, 75015 Paris, France. ${ }^{3}$ Microbial Evolutionary Genomics Unit, CNRS UMR 3525, Institut Pasteur, 75015 Paris, France. ${ }^{4}$ Université Paris Diderot, Université de Paris, 75013 Paris, France. 5 Paris Descartes University, Institut Imagine, Necker-Enfants Malades University Hospital, Division of Infectious Diseases and Tropical Medicine, APHP, 75006 Paris, France. ${ }^{6}$ Present address: Biodiversity and Epidemiology of Bacterial Pathogens Unit, Institut Pasteur, 75015 Paris, France. Correspondence and requests for materials should be addressed to M.L. (email: marc.lecuit@pasteur.fr)
} 